UDK 623.454.8(497.1)

https://doi.org/10.18485/fb_ic4hs.2018.5

\title{
OPEN DATA AND AVAILABLE RESEARCH ON DEPLETED URANIUM WEAPONS - REASONS FOR CONTROVERSY (YUGOSLAVIA 1999 - CASE STUDY)
}

\author{
Nada SEKULIĆ*
}

\begin{abstract}
The paper addresses the question: How is public opinion built in the absence of reliable data? The theoretical background in this approach is based on the theories of public opinion which assume that "individuals do not turn to media primary for truth or information, they turn to the media to help themselves define social reality" (Moy \& Bosch, 2013). This means that public opinion, and particularly public opinion on controversial issues which are not presented in a transparent and objective way, is built on stereotypes framed by political assumptions and affinities, without making a clear distinction between facts and preferences.

The paper presents the results of an online survey conducted on a sample of 534 Serbian citizens, in which we tried to use the approach mentioned above as a hypothesis and to operationalize and prove it by covering the issue of the usage of depleted uranium (DU) weapons in the 1999 NATO bombing of the FRY. The results show that the attitude about the harmful effects of DU munitions depends strongly on the political affinities of the respondents towards the East or the West and on their views on how the crises in Kosovo should be resolved. It also correlates strongly with their positive/negative identification with the Serbian national identity.
\end{abstract}

Keywords: depleted uranium, military operation "Noble Anvil", public opinion on the NATO bombing of the FRY

\section{INTRODUCTION}

On May 18, 2018, nearly twenty years after the NATO military intervention against the FRY, the government of Serbia established a special commission with the task of estimating the effects of the usage of depleted uranium (DU) during the military intervention "Noble Anvil". During these two decades, the chances to thoroughly and continually monitor the citizens and areas which had been exposed to DU was lost, in spite

\footnotetext{
* Full Professor, PhD, University of Belgrade Faculty of Philosophy, wu.wei@orion.rs
} 
of the fact that the bombing of the FRY was the first case in which NATO was forced to publicly confirm the usage of DU munitions.

In the absence of a clear strategy and action plan by the state, which would provide information about the facts, various controversial pieces of information have emerged in the media estimating the scope of the ecological disaster produced by DU weapons. The issues of DU's carcinogenic activity and whether there has been a disproportionate increase in malignancies in Serbia over the past two decades have been particularly controversial. Experts and laymen - politicians, celebrities, doctors, NGO activists, lobbyists, lawyers, public figures - all gave statements to the media, which were often brought into the spotlight in sensational talk shows. They provided little explanatory information about cognitive, military-political or ethical concerns. Dramatic images of public battles and unpleasant situations among the guests of these shows increased the ratings of these programs, but did not contribute to the development of objective and impartial journalism.

In such context, the public has not had enough sources and open social space to develop a rational and cognitive approach to the issue.

\section{THE ONLINE SURVEY}

\section{"IMPACT OF PUBLIC POLITICAL PREFERENCES ON ATTITUDES ABOUT DETRIMENTAL EFFECT OF DEPLETED URANIUM (DU) WEAPONS"}

An online pilot survey was conducted on a sample of 534 respondents. The survey was publicly distributed on the Facebook social network during the summer of 2018 and was available until it was filled in by around 500 respondents. The only requirement for the respondents was that they were citizens of Serbia (including those with dual nationality, who encompassed $3.8 \%$ of the sample). The data were not used for generalizations, but with the preliminary purpose of examining the structure of responses and the interdependence between four groups of questions/topics: 1) attitudes of the respondents about the detrimental effects of depleted uranium, 2) the political preferences of the respondents regarding the status of Kosovo, 3) political preferences towards Western or Eastern countries/political blocks, 4) affirmative/negative attitudes toward the Serbian identity and Serbian self-identification.

The main aim of this research was to examine if and how much the public opinion relating to DU was influenced by the broader public's political opinions and preferences.

The research uncovered "deep play" (Geertz, 2005) between opposing political groups/subjects, in which a cognitive issue (the detrimental effects of DU) becomes the stake in their public gaming/betting for social approval and support. This political battle has the "all-or-nothing" form, since audience cannot bet on both sides/parties and have to choose only one political side/party. Just as in the case of the Balinese cocks in Geertz's story of the Balinese, here we have "deep play", which transfers the debate and raw fight between political groups to the "pseudo-cognitive" debate on DU. This debate also takes 
the form of an "all-or-nothing" discourse aiming at persuasion between "right" and "wrong", which is a form of political betting.

Since most of the respondents (83\%) declared themselves as Serbian $(9.9 \%$ did not answer the question, 2.2\% are Yugoslav and all other options are below 1\%), we could also interpret the data referring to the Serbian identity as positive or negative ethnic selfidentification.

\section{DESCRIPTIVE ANALYSES}

\subsection{ATTITUDES ABOUT THE DETRIMENTAL EFFECTS OF DEPLETED URANIUM (ADU)}

This group of questions included six statements, which were used as a composite variable defining the attitude of the respondents towards the detrimental effects of depleted uranium, with an emphasis on its carcinogenic effects. The list of responses offered in the online questionnaire was longer, but these six items satisfied the requirements of consistency, homogeneity and normal distribution.

Table 1. Items of the composite variable: Attitudes about the detrimental effects of depleted uranium (with an emphasis on its carcinogenic effects), and the correlation matrix between them

$1=$ strongly disagree, $2=$ partially disagree, $3=$ neither, $4=$ partially agree, $5=$ strongly agree $\mathbf{R}=$ responses that required reverse scoring

\begin{tabular}{|r|l|c|c|c|c|c|}
\hline & \multicolumn{1}{|c|}{$\%$} & 1 & 2 & 3 & 4 & 5 \\
\hline 1 & $\begin{array}{l}\text { (I believe that) bombs with depleted } \\
\text { uranium cause cancer. }\end{array}$ & 8.4 & 5 & 17 & 20.8 & 49 \\
\hline 2 & $\begin{array}{l}\text { A lot of research and data confirm the } \\
\text { devastating effects of depleted uranium, but } \\
\text { their publication is being obstructed. }\end{array}$ & 11.6 & 8 & 32.4 & 20.6 & 27.4 \\
\hline 3 & $\begin{array}{l}\text { In Serbia there has been an extraordinary } \\
\text { increase in the number of cancer diseases } \\
\text { due to the depleted uranium bombing. }\end{array}$ & 9.2 & 6.7 & 23.7 & 23.5 & 37 \\
\hline 4 & $\begin{array}{l}\text { It was high time for the Serbian } \\
\text { government to form a commission to } \\
\text { investigate the consequences of the 1999 } \\
\text { NATO bombing. }\end{array}$ & 10.9 & 4.2 & 16 & 18.3 & 50.6 \\
\hline 5 & $\begin{array}{l}\text { R It has been scientifically proven that } \\
\text { depleted uranium bombing does not cause } \\
\text { cancer. }\end{array}$ & 46.1 & 9.9 & 31 & 5.1 & 7.8 \\
\hline 6 & $\begin{array}{l}\text { R It is irresponsible to confuse people with } \\
\text { questions about depleted uranium twenty } \\
\text { years after the bombing. }\end{array}$ & 43.8 & 17 & 11.3 & 13 & 14.9 \\
\hline
\end{tabular}


Correlation matrix (Pearson's):

\begin{tabular}{|c|c|c|c|c|c|c|}
\hline & 1 & 2 & 3 & 4 & 5 & 6 \\
\hline 1 & 1.00 & .684 & .793 & .610 & .686 & .558 \\
\hline 2 & .684 & 1.00 & .672 & .528 & .566 & .423 \\
\hline 3 & .793 & .672 & 1.00 & .615 & .630 & .537 \\
\hline 4 & .610 & .528 & .615 & 1.00 & .500 & .535 \\
\hline 5 & .686 & .566 & .630 & .500 & 1.00 & .504 \\
\hline 6 & .558 & .423 & .537 & .535 & .504 & 1.00 \\
\hline
\end{tabular}

Cronbach's alpha=0.893; Mean: .589; Min..423, Max..793; Kaiser-Meyer-Olkin Measure $=.897$; Bartlett's test of Sphericity (Sig.) $=.000$

The responses show that majority of the respondents believe that DU bombs (i.e. munitions) have carcinogenic effects. According to their responses, this has also been the main cause of the increase in carcinogenic diseases in Serbia since the 2000s. Most of them take the health issue caused by the 1999 bombing very seriously and think that the Serbian government still has a duty to investigate the case. The majority of them do not agree with the statement that it has been scientifically proven what exactly is the effect of DU bombing and believe that the publication of the data that question NATO's reports have been obstructed. In addition, only $6.7 \%$ trust the reports of NATO (NATO's reports do not confirm the carcinogenic influence of DU munitions). (Due to the lack of normal distribution, the last statement was unsuitable to be included in the composite variable and was analyzed as independent variable - almost $80 \% / 78.9 \% /$ of the respondents do not trust NATO's research and public data on nuclear weapon.)

\subsection{THE POLITICAL PREFERENCES OF THE RESPONDENTS REGARDING THE STATUS OF KOSOVO (AK)}

The composite variable was made of eight statements which related to the respondents' understanding of the political crises in Kosovo and their vision for the solution of the problem. These eight statements proved to be consistent and suitable in all aspects for parametric analyses. The table below shows the respondents' choices and the correlation matrix between these eight statements. 
Table 2. The political preferences of the respondents regarding the status of Kosovo and the correlation matrix between them

$1=$ strongly disagree, $2=$ partially disagree, $3=$ neither, $4=$ partially agree, $5=$ strongly agree

$\mathbf{R}=$ responses that required reverse scoring

\begin{tabular}{|c|c|c|c|c|c|c|}
\hline & $\%$ & 1 & 2 & 3 & 4 & 5 \\
\hline 1 & $\begin{array}{l}\text { Instead of being put behind bars for } \\
\text { organizing the bombing of the FRY, } \\
\text { Madeleine Albright and Wesley Clark } \\
\text { are buying mines and businesses in } \\
\text { Kosovo. }\end{array}$ & 5.2 & 3.4 & 22.5 & 19.7 & 49.2 \\
\hline 2 & Kosovo is Serbia. & 16.8 & 8.2 & 14.3 & 11.9 & 48.8 \\
\hline 3 & $\begin{array}{l}\text { The attitude of Albanians towards the } \\
\text { monuments of Serbian medieval } \\
\text { Orthodox culture in Kosovo is in } \\
\text { itself a sufficient reason for Serbia } \\
\text { not to recognize Kosovo. }\end{array}$ & 10.9 & 11.1 & 16.3 & 14.9 & 46.7 \\
\hline 4 & Kosovo - the heart of Serbia. & 25.1 & 10.2 & 17.8 & 12.3 & 34.7 \\
\hline 5 & $\begin{array}{l}\text { Concerning Serbian culture in } \\
\text { Kosovo, Albanians are the same as } \\
\text { the Taliban. }\end{array}$ & 8.2 & 7.3 & 18 & 16.1 & 50.5 \\
\hline 6 & $\begin{array}{l}\text { R Whether someone likes it or not, } \\
\text { the fact is that Serbia has lost } \\
\text { Kosovo. }\end{array}$ & 24.7 & 12.2 & 14.9 & 20.1 & 28.1 \\
\hline 7 & $\begin{array}{l}\mathbf{R} \text { Serbian property in Kosovo is lost. } \\
\text { It's best not to discuss it again. }\end{array}$ & 45.6 & 17.2 & 10.9 & 15.1 & 11.3 \\
\hline 8 & $\begin{array}{l}\mathbf{R} \text { Serbian generals who hide their } \\
\text { responsibility for killing Albanian } \\
\text { civilians in Kosovo do not have the } \\
\text { legitimacy to speak about the harmful } \\
\text { consequences of the FRY bombing. }\end{array}$ & 23.2 & 9 & 21.5 & 20.3 & 26.1 \\
\hline
\end{tabular}

Correlation matrix (Pearson's):

\begin{tabular}{|c|c|c|c|c|c|c|c|c|}
\hline & 1 & 2 & 3 & 4 & 5 & 6 & 7 & 8 \\
\hline 1 & 1.00 & .484 & .459 & .478 & .421 & .411 & .329 & .320 \\
\hline 2 & .484 & 1.00 & .704 & .775 & .458 & .654 & .618 & .469 \\
\hline 3 & .459 & .704 & 1.00 & .650 & .422 & .523 & .498 & .385 \\
\hline 4 & .478 & .775 & .650 & 1.00 & .394 & .620 & .549 & .507 \\
\hline 5 & .421 & .458 & .422 & .394 & 1.00 & .328 & .289 & .318 \\
\hline 6 & .411 & .654 & .523 & .620 & .328 & 1.00 & .657 & .468 \\
\hline 7 & .329 & .618 & .498 & .549 & .289 & .657 & 1.00 & .398 \\
\hline 8 & .320 & .469 & .385 & .507 & .318 & .468 & .398 & 1.00 \\
\hline
\end{tabular}


Cronbach's alpha: .883; Mean: .485, Min. 289, Max.775; Kaiser-Meyer-Olkin Measure $=.902$; Bartlett's test of Sphericity (Sig. $)=.000$

The list of the offered responses related to Kosovo was longer, but not all of them could be included in the composite variable. Some of these responses show that the majority of the respondents have an almost identical opinion regarding certain issues $-81.7 \%$ of the respondents do not agree with the attitude that Serbs got what they deserved in Kosovo, $79.4 \%$ think that Albanians conducted preplanned cultural genocide against Serbs in Kosovo, and $65.2 \%$ are against the recognition of Kosovo.

The indicators included in the common variable cover the issue of Serbian war crimes in Kosovo, the issue of Serbian property in Kosovo, Albanian destruction of Orthodox heritage and Serbian culture in Kosovo and attitudes about the independence of Kosovo.

\subsection{POLITICAL PREFERENCES TOWARDS EASTERN/WESTERN POLITICAL ALLIES (AEW)}

We combined eight indicators into a single variable measuring the respondents' political preferences towards the East or West. Conceptually and statistically, this variable proved to be consistent and suitable for further analyses as well. It encompassed a range of statements related to Serbia's potential membership in the EU, military cooperation with Russia, positive or negative attitudes towards the German/Russian people, and the affinity towards public figures such as Russian president Vladimir Putin. All statements were designed to measure solidarity, affinity, the political assessment of the East or West and the ideas about what kind of military alliances would be best for the future of Serbia.

Table 3. The political preferences regarding Eastern/Western countries and the correlation matrix between them

$1=$ strongly disagree, $2=$ partially disagree, $3=$ neither, $4=$ partially agree, $5=$ strongly agree $\mathbf{R}=$ responses that required reverse scoring

\begin{tabular}{|r|l|c|c|c|c|c|}
\hline & \multicolumn{1}{|c|}{$\%$} & 1 & 2 & 3 & 4 & 5 \\
\hline 1 & $\begin{array}{l}\text { The construction of a Russian military base } \\
\text { near Niš should be allowed. }\end{array}$ & 29 & 10.3 & 21.4 & 12.6 & 26.7 \\
\hline 2 & Russians are our brothers. & 24.9 & 12.6 & 21.8 & 18.4 & 22.2 \\
\hline 3 & EU leaders do not want a strong Serbia. & 11.7 & 9.8 & 20.3 & 16.5 & 41.8 \\
\hline 4 & Putin is a tsar. & 30.6 & 10.1 & 20.5 & 14.3 & 24.5 \\
\hline 5 & Germans have always been our enemies. & 21.2 & 19.7 & 23.9 & 15.7 & 19.5 \\
\hline 6 & $\begin{array}{l}\text { If Serbia needs a military ally, then it } \\
\text { should be Russia. }\end{array}$ & 23.4 & 9.8 & 20.9 & 18.4 & 27.4 \\
\hline 7 & $\begin{array}{l}\text { It's better for Serbia to cooperate more with } \\
\text { the East than with the West. }\end{array}$ & 18.4 & 12.8 & 34.5 & 16.5 & 17.8 \\
\hline 8 & R Serbia should join the EU. & 33.6 & 14.8 & 13.4 & 16.5 & 21.7 \\
\hline
\end{tabular}


Correlation matrix (Pearson's):

\begin{tabular}{|c|c|c|c|c|c|c|c|c|}
\hline & 1 & 2 & 3 & 4 & 5 & 6 & 7 & 8 \\
\hline 1 & 1.00 & .697 & .435 & .705 & .451 & .686 & .628 & .400 \\
\hline 2 & .697 & 1.00 & .475 & .775 & .491 & .747 & .638 & .406 \\
\hline 3 & .435 & .475 & 1.00 & .451 & .406 & .496 & .430 & .457 \\
\hline 4 & .705 & .775 & .451 & 1.00 & .446 & .736 & .650 & .431 \\
\hline 5 & .451 & .491 & .406 & .446 & 1.00 & .538 & .446 & 388 \\
\hline 6 & .686 & .747 & .496 & .736 & .538 & 1.00 & .770 & .524 \\
\hline 7 & .628 & .638 & .430 & .650 & .446 & .770 & 1.00 & .516 \\
\hline 7 & .400 & .406 & .457 & .431 & .388 & .524 & .516 & 1.00 \\
\hline
\end{tabular}

Cronbach's alpha: .905; Mean: .543, Min..388, Max.775; Kaiser-Meyer-Olkin Measure $=.911$; Bartlett's test of Sphericity (Sig.) $=.000$

\subsection{SERBIAN IDENTITY - POSITIVE/NEGATIVE IDENTIFICATION}

In addition, the questionnaire included one battery of statements referring to the positive/negative orientation towards the Serbian identity and the main symbols of Serbian identity. Since the responses for these statements do not have a normal distribution, we used only several of them as independent variables and analyzed them using a nonparametric $\mathrm{HI}-$ test.

Table 4. Positive/negative attitudes towards the Serbian identity $1=$ strongly disagree, $2=$ partially disagree, $3=$ neither, $4=$ partially agree, $5=$ strongly agree

\begin{tabular}{|r|l|c|c|c|c|c|}
\hline & $\%$ & 1 & 2 & 3 & 4 & 5 \\
\hline 1 & The Cyrillic alphabet is obsolete. & 75.1 & 9.6 & 6.9 & 4.2 & 4.2 \\
\hline 2 & $\begin{array}{l}\text { Sometimes I'm ashamed of being from } \\
\text { Serbia. }\end{array}$ & 58.4 & 10.2 & 6.1 & 13.2 & 12.1 \\
\hline 3 & $\begin{array}{l}\text { People in Serbia are primitive and it will } \\
\text { take a long time for us to get closer to the } \\
\text { European level of culture. }\end{array}$ & 36.3 & 14.9 & 13.6 & 20.7 & 14.5 \\
\hline 4 & $\begin{array}{l}\text { When I'm abroad I don't like people to } \\
\text { know I'm from Serbia. }\end{array}$ & 79.3 & 8.4 & 5.2 & 3.4 & 3.4 \\
\hline
\end{tabular}




\section{Parametric analyses and $\chi^{2}$ test}

The aim of this part of the analysis was to show how much the attitudes concerning DU (composite variable ADU) were determined by the political orientations/preferences of the respondents (composite variable $\mathrm{AEW}, \mathrm{AK}$ ) and if the attitude on DU was related to the positive/negative Serbian ethnic self-identification.

Multiple regression was applied on three composite variables - ADU (attitudes about the detrimental effects of depleted uranium) as a dependent variable and AEW (the political preferences regarding Eastern/Western countries and the correlation matrix between them) and AK (the political preferences of the respondents regarding the status of Kosovo) as predictors.

Analyses show strong correlations between these three variables:

Table 5. Correlations between composite variables ADU, AK and AEW

\begin{tabular}{|l|l|c|c|c|}
\hline & & 1 ADU & $2 \mathrm{AK}$ & $3 \mathrm{AEW}$ \\
\hline 1. & ADU (Attitudes about DU) & 1.00 & .673 & .623 \\
\hline 2. & AK (Attitudes about Kosovo) & .673 & 1.00 & .768 \\
\hline 3. & $\begin{array}{l}\text { AEW (Attitudes about } \\
\text { Eastern/Western Allies) }\end{array}$ & .623 & .768 & 1.00 \\
\hline
\end{tabular}

Parson's corr. Sig. 000

Since the correlations between AK and AEW were too high (above 0.700), which implies that these two composite variables measured almost the same thing, they were merged into one variable. The new composite variable (AK/AEW) correlates strongly with the dependent variable AK (0.690). The assumption of normality, multicollinearity and homogeneity of variance was not violated. The regression model explains $47.6 \%$ of the variance $\left(\mathrm{R}^{2}=.476\right.$; Sig. 000$)$, which means that the analyses confirmed a strong influence of the respondents' political preferences on their attitudes about the detrimental effects of DU. This means that we can predict public attitudes on DU by knowing the political preferences concerning the political solution for Kosovo's crises or the preferences for certain political alliances. The fact that somebody strongly supports Kosovo's independence or argues in favor of NATO allies can be interpreted as a predictor of their attitudes about the toxicological and radiological effects of DU.

In addition, the interconnection between ADU (attitudes about the detrimental effects of DU) and positive/negative Serbian self-identification was measured using HI-square analyses. The analyses confirm a significant connection $(\mathrm{p}<0.05)$. The increase in negative attitudes toward Serbian self-identification is accompanied by a decrease in negative attitudes towards the detrimental effects of DU. The respondents who have negative Serbian self-identification are exactly those who share the attitude that DU is not related to cancer and that its detrimental effects are low. This pattern was confirmed in the comparison of all the measured statements (table 6). 
Table 6. Interconnection (Hi-square measurement) between positive/negative attitudes toward the Serbian identity (self-identification) and ADU (attitudes about the detrimental effects of $\mathrm{DU})$

- = negative

$+=$ positive

$\mathrm{N}=$ neutral

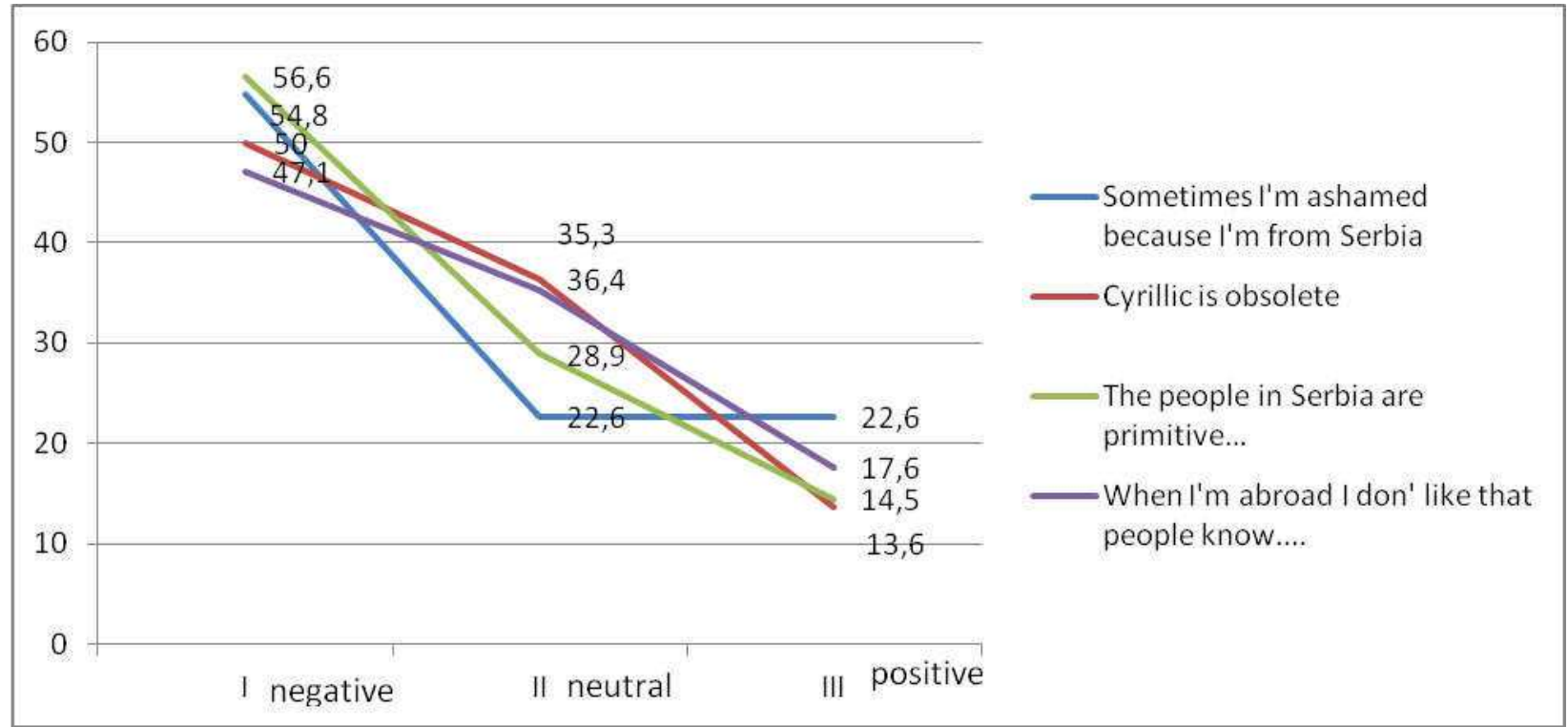

\begin{tabular}{|c|c|c|c|c|}
\hline$\%$ & - & $\mathrm{N}$ & + & $\chi^{2}$ \\
\hline The Cyrillic alphabet is obsolete. & 50 & 36.4 & 16.3 & $\begin{array}{c}\chi 2=54.99 \\
\text { Sig.000 } \\
\text { Cramer's } \\
V=.230\end{array}$ \\
\hline $\begin{array}{l}\text { Sometimes I'm ashamed because I'm } \\
\text { from Serbia. }\end{array}$ & 54.8 & 22.6 & 22.6 & $\begin{array}{c}\chi 2=45.23, \\
\text { Sig. } 000 \\
\text { Cramer's } \\
\text { V=.209 }\end{array}$ \\
\hline $\begin{array}{l}\text { When I'm abroad I don't like people to } \\
\text { know I'm from Serbia. }\end{array}$ & 47.1 & 35.3 & 17.6 & $\begin{array}{c}\chi 2=24.5724 .57, \\
\text { Sig.002, } \\
\text { Cramer's } \\
\text { V=.154 }\end{array}$ \\
\hline $\begin{array}{l}\text { People in Serbia are primitive and it will } \\
\text { take a long time for us to get closer to the } \\
\text { European level of culture. }\end{array}$ & 56.6 & 28.9 & 14.5 & $\begin{array}{c}\chi 2=47.07, \\
\text { Sig. } 000, \\
\text { Cramer's V= } \\
.213\end{array}$ \\
\hline
\end{tabular}




\section{CONCLUSION}

In this paper, we have tried to examine some aspects of the public opinion dynamics in the debate on DU weapons. The analyses show a strong influence of the need for social grouping regarding public attitudes about the detrimental effects of DU, which is basically a cognitive issue.

The conclusion of the paper is that the public atmosphere related to the debate on this issue favors the social dynamics of "a psychological crowd", which is a signal of mass culture and society, but not of a democratic, attentive and cognitive media audience, stirring conflicts and increasing "the public fog" in which it will not be possible to present the objective scope of damage and develop beneficial and responsible political strategies.

\section{REFERENCES:}

Bennet T. (1982). "Theories of Media, Theories of Society". in Gurevitch M.(ed.): Culture, Society and the Media, London: Methuen

Bon Le G.(2005): Psihologija gomile, Beograd: Algoritam

Capstone Deleted Uranium Aerosols. (2004). Report. Pacific Northwest National Laboratory

"Depleted uranium and Canadian Veterans"(2013). Scientific Advisory Committee on Veterans' Health

"Depleted Uranium in Serbia and Monte Negro. Post-conflict Environmental Assessment in the FRY". (2002), Switzerland, UNEP (Unated Nations Environment Programme)

Evert P., Isernia P. (eds.) (2001). Public Opinion and the International Use of Force. London, New York: Routledge

Geertz C. (2005): "Deep Play: Notes on the Balinese Cockfight". Daedalus, Fall 134:4. (pp 56-86)

Ginneken van J. (2003). Collective Behaviour and Public Opinion, Mahwah, New Jersey, London: Lawrence Erlbaum Associates Publ.

Institute of Medicine. (2008). Gulf War and Health. Committee of Gulf War And Health, Washington: The National Academy Press

Laswell H.D. , Blumenstok D. (2006): World Revolutionary Propaganda, San Francisco: Alfred A. Knopf

Liolios Th.E. (1999). "Assessing the risk of the DU used in the operation Allied Forces", Science \& Global Security, Volume 8:2, (pp 163-181)

Lippmann W (1922). The Public Opinion, New York: Harcout

Lippmann W.(1993/1925). The Phantom Public, New Brunswick, London: Transaction Publishers

Malignant Effects: Depleted uranium as genotoxin and carcinogen. (2012). ICBUW (International Coalition to Ban Uranium Weapons), Manchester: ICBUW

Moy P., Bosch B. (2013). "Theories of Public Opinion" Sociology Department. Faculty Publications. 244, University of Nebraska- Lincoln 
Orlic M. (2000). "Osiromaseni uranijum kao produkt nuklearne tehnologije", XLIV konferencija za ETRAN, Sokobanja 26-29. jun.

Pavlovic R, Pavlovic S., Sipka D., Todorovic D., Paligoric D., Radenkovic M., Djuric J. (2001): "Osiromaseni uranijum u agresiji NATO na FRJ", rad saopsten na seminaru: "Osiromaseni uranijum - istine i zablude", jun, Beograd, Hem.ind. 55:7-8, pp.309-317

Petkovic S., Zaric M., Devic Z. (2001). "Upotreba municije sa osiromasenim uranijumom u agresiji NATO na FRJ". Rad saopsten na seminaru: "Osiromaseni uranijum istine i zablude", jun, Beograd Hem.ind. 55:7-8, (pp.318-324)

Review of Toxicologic and Radiologic Risks to Military Personnel from Exposure to DU During and After Combat. (2008) National Research Council, http://www.nap.edu/catalog/11979.html, Retrieved on 9/8/2018.

Visser M. (1998). Five Theories of Voting Actions, Twente University Press

Facts on Depleted Uranuim (2001). papers submitted to the conference. Prague. https://inis.iaea.org/collection/NCLCollectionStore/_Public/34/083/34083234.pdf Retrieved on: 9/8/2018 